\title{
COMMENTS
}

\section{APPLICABILITY OF THE IMMUNITY OF SECTION 7a(10) OF THE BANKRUPTCY ACT TO REPRESENTATIVES OF A CORPORATE BANKRUPT}

Among the devices arrayed by the Bankruptcy Act $^{1}$ to yield that quantum of information which is indispensable to the administration of a bankrupt estate are examinations of the bankrupt and other persons. Section $7 \mathrm{a}(\mathrm{ro})^{2}$ and section $2 \mathrm{Ia}^{3}{ }^{8}$ couched in terms so broad as to license virtually any inquiry which may assist the court in administering the estate of the bankrupt, ${ }^{4}$ contain the major provisions for examination. Attendance at and conduct in the specified examinations are subject to regulation by way of power to punish for contempt. ${ }^{5}$

Militating against full disclosure, however, is the well-established right of the bankrupt or other persons subject to examination under the Act to claim the protection of the fifth amendment against self-incrimination. ${ }^{\circ}$ But in so far as the bankrupt is concerned, refusal to answer a material question on the ground of self-incrimination will constitute

\footnotetext{
1 so Stat. 544, as amended (1898); Ir U.S.C. $\$ \S 1-1$ 103, as amended (1946).

2 "The bankirupt shall ... (10) at the first meeting of his creditors, at the hearing upon objections, if any, to his discharge and at such other times as the court shall order, submit to an examination concerning the conducting of his business, the cause of his bankruptcy, his dealings with his creditors and other persons, the amount, kind, and whereabouts of his property, and, in addition, all matters which may affect the administration and settlement of his estate or the granting of his discharge. ..."

3 "The court may, upon application of any officer, bankrupt, or creditor, by order require any designated persons, including the bankrupt and his or her spouse, to appear before the court or before the judge of any State court, to be examined concerning the acts, conduct, or property of a bankrupt. ..."

"See I Collier, Bankruptcy II 7.15-7.23 (14th ed., Moore, 1945) (hereinafter cited as COLLIER); 2 id. II 2 r.or-21.23.

${ }^{5}$ Section $22\left(\mathrm{r}_{3}\right)$ of the Act empowers the bankruptcy courts "to enforce obedience by persons to all lawful orders, by fine or imprisonment or fine and imprisonment." Section 41 affords sanctioning power for contempts before referees.

- McCarthy v. Arndstein, 266 U.S. 34 (1924); Arndstein v. McCarthy, 254 U.S. 71 (1920); Matter of Hooks Smelting Co., 138 Fed. 954 (E.D. Pa. 1905). In general as to the extent of the privilege against self-incrimination, see $x$ CoLLIIER $\{7.2132 \mathrm{dd}$. I 21.14; 5 Remington, BANKruptcx $\S \S$ 2004-2006 (5th ed., Henderson, 1955) (hereinafter cited as REMINGTON); 9 id. $\$ \S 3512-15$.
} 
the basis for denial of discharge under section $I 4 C(6) ;^{7}$ and this subtle sanction may well persuade the individual bankrupt to forego assertion of his constitutional privilege. Moreover, a clause within section $7 \mathrm{a}$ ( 10 ), itself, inevitably will reinforce any inclination to maximum disclosure. It is there provided:

[N]o testimony given by [the bankrupt] shall be offered in evidence against him in any criminal proceeding, except such testimony as may be given by him in the hearing upon objections to his discharge. ...

As a practical matter, however, the scope of the immunity thus conferred by the Act is not so broad as might appear. ${ }^{8}$ No bar is posed to a subsequent criminal prosecution; the immunity applies only to the use of certain material in such a prosecution. The protection is accorded only to the oral testimony ${ }^{9}$ of the bankrupt, uttered in an examination which he was compelled to attend, ${ }^{10}$ and although the immunity is seemingly recognized in state as well as federal courts, ${ }^{11}$ it has no application in civil proceedings. Expressly, there is, of course, no immunity accorded testimony given at the hearing upon objections to discharge, and a broad exception to the immunity rule is recognized in criminal actions for perjury or contempt, where the very words of the bankrupt must be proved in order to sustain the charge against him. ${ }^{12}$ Furthermore, the bankrupt's privilege under section $7 a$ (ro) may be waived and is waived by failure to make apt and timely assertion of it. ${ }^{13}$

Despite the eroding effect of the foreging exceptions and limitations, the scope of the $7 \mathrm{a}$ (ro) immunity is substantial, and it has occasioned a considerable amount of litigation-litigation which has left at least one significant question without definitive answer: Is the testimony of directors, stockholders, offcers, or members of a bankrupt corporation

\footnotetext{
${ }^{7}$ Kaufman v. Hurwitz, 176 F.2d 210 (4th Cir. 1949); In re Dresser, 146 Fed. ${ }_{3}^{8} 3$ (zd Cir. Ig06).

${ }^{8}$ See I Collier If 7.21; 9 Remingron $§ \S$ 3506-11.

${ }^{\circ}$ Ensign v. Pennsylvania, 227 U.S. 592 ( 1913 ).

${ }^{20}$ Ibid. Cf. White v. United States, 30 F.2d 590 (Ist Cir. 1929); Goldstein v. United States, II F.2d 593 (5th Cir. 1926).

${ }^{11}$ See cases cited at I CoLLIER I 7.2 I n. 25. But cf. In re Nachman, 114 Fed. 995 (D.S.C. 1902).

${ }^{28}$ Cameron v. United States, 23 I U.S. 710 (1914); Glickstein v. United States, 222 U.S. 139 (1911) ; In re Kaplan, 213 Fed. 753 (3d Cir.), cert. denied, 234 U.S. 765 (1914). But cf. United States v. Weissman, 219 F.2d 837 (2d Cir. 1955).

${ }^{18}$ Bain v. United States, 262 Fed. 664 (6th Cir.), cert. denied, 252 U.S. 586 (I920).
} 
privileged, whether adduced either under section 7 or section 2 Ia examinations?

\section{Section 7 a Examinations}

Of relevance in defining the immunity attaching to testimony elicited in the course of examinations conducted under section $7^{a}$ is section $7 b$, added to the Act in $1938,{ }^{14}$ which provides that in a case where the bankrupt is a corporation, the duties imposed upon it shall be performed by officers, directors, stockholders, or members thereof as designated by the court. ${ }^{15}$ Evidently this section was enacted merely to codify what had, of necessity, been the previous practice. ${ }^{16}$

It is probably accurate to say that prior to the enactment of section $7 \mathrm{~b}$, the weight of authority was to the effect that the immunity accorded the bankrupt's testimony could not be claimed by the representative of a corporate bankrupt. ${ }^{17}$ Indeed, immediately following the addition of section $7 \mathrm{~b}$, a dictum ${ }^{18}$ reaffirmed this pre-existing law. Dictum in a more recent decision ${ }^{19}$ by the same court, however, indicates that a sole share-

${ }^{14} 52$ Stat. 848 (1938), II U.S.C. § 25 (b) (1946).

${ }^{15}$ It is generally held that persons withdrawing from such positions prior to the bankruptcy proceeding can be examined only under § 21 a. E.g., In re Bush Terminal Co., 102 F.2d 471 (2d Cir. 1939). But see Greene v. Harris, 240 F.2d 275, 276 (2d Cir. 1957), where a gaping loophole is closed by this language: "Nothing in [\$ $7 \mathrm{~b}]$ or its background suggests that it should be construed so narrowly as to allow evasion of its salutary purposes by the patent device of resignation just prior to bankruptcy."

${ }^{10}$ In re Alphin \& Lake Cotton Co., I3I Fed. 824 (E.D. Ark. I904). I Collier I $7.25 ; 5$ REMINGTON $\$ 1983$.

${ }^{17}$ In People v. Lay, 193 Mich. 17, I59 N.W. 299 (1916), it was held that such testimony is privileged and should be if the purposes of the Act are to be subserved. Dictum of In re Alphin \& Lake Cotton Co., I3I Fed. 825, 826 (E.D. Ark. 1904), indicates a similar conclusion: "[The testimony of officers of a bankrupt corporation] taken under section 7 or 21 . . was clearly admissible in any proceeding against them, other than criminal, as admissions against themselves." (Emphasis added.) Cf. Clark v. State, 68 Fla. 433, 67 So. 135 (1914). In Kaplan v. United States, 7 F.2d 594 (2d Cir.), cert. denied, 269 U.S. 582 (1925), however, the position was taken that the representatives of a bankrupt corporation are not protected under the immunity clausc. This conclusion was fortifed when, in Kolbrenner v. United States, II F.2d 754, 756 (5th Cir.), cert. denied, 27I U.S. 677 (1926), the rule of People v. Lay was expressly rejected.

${ }^{18}$ In re Bush Terminal Co., Ioz F.2d 47 I (2d Cir. 1939): "Section 7 deals with the duties of bankrupts and, while corporate bankrupts must act in the performance of those duties by representatives having authority to perform them for such bankrupts, it does not follow that even those who do act for the bankrupt are to be treated as the bankrupt. For instance, they are not protected under Sec. 7(9) [the predecessor of $\S 7 \mathrm{a}(\mathrm{ro})] . "$

${ }^{10}$ United States v. Weissman, 2 I9 F.2d 837, 841 (2d Cir. I955). 
holder designated by a court pursuant to section $7 \mathrm{~b}$ to perform the duties of the bankrupt corporation can claim the privilege of section $7 \mathrm{a}$ (IO). Moreover, this same dictum would seem to imply that the different rule should obtain just by reason of the enactment of section $7 \mathrm{~b} .^{20}$ Thus, although it would be difficult exactly to define the state of the law on this point today, some judicial support can be found for the proposition that representatives of corporate bankrupts examined under section 7 should be entitled to claim the immunity of section $7 \mathrm{a}(\mathrm{IO})$; and most commentators appear to support this view. ${ }^{21}$ Indeed, a literal interpretation of section 7 , taken as a whole, would seem reasonably to indicate that a director or other represenative of a corporate bankrupt acting pursuant to section $7 b$ is assimilated to the bankrupt in so far as all the provisions of section 7 are concerned.

But what was the legislative intent?

It seems clear that the underlying purpose of Congress originally was to conduce the thorough and equitable administration of the bankrupt estate, which purpose squarely depends for fulfillment upon encouraging disclosure of a maximum of information relative to the bankrupt's property and his business affairs. ${ }^{22}$ Any possible doubt that this was the dominant congressional purpose was dispelled by the enactment in $1938^{23}$ of the proviso that no immunity can be claimed for testimony received at the hearing upon objections to discharge in bankruptcy. Although the bankrupt must appear at such a hearing if he hopes to be discharged, no similar public purpose would be served by extending immunity to testimony therein elicited; only private interests, personal to the bankrupt, would be thereby advanced. In a real sense, the burden of disproving disparaging allegations is upon the bankrupt. Therefore, only disclosures of a self-serving nature can affect the outcome of this hearing.

${ }^{20}$ Ibid. The Second Circuit also decided Kaplan v. United States, 7 F.2d 594 (2d Cir.), cert. denied, 269 U.S. 582 (1925), and In re Bush Terminal Co., 102 F.2d 471 (2d Cir. 1939). In United States ซ. Weissman, the court distinguished In re Bush Terminal Co. on the ground that the latter case had not involved anyone desiguated by the court to perform the bankrupt's duties. No reference was made to Kaplan v. United States, evidently because it had been decided prior to enactment of section $7 \mathrm{~b}$.

${ }^{31}$ E.g., COLLIER I 7.2 I n. 27; REMINGTON $\$ 2008$; Note, 28 ST. John's L. REV. 259, 264 (1954), reprinted in 28 REF. J. 132 (1954).

${ }_{29}$ People v. Lay, I93 Mich. 17, 30, 159 N.W. 299, 303 (1916); United States v. Weissman, 219 F.2d 837, 84 I (2d Cir. 1955).

${ }^{28} 52$ Stat. 847 (1938), ir U.S.C. \$ 25 (10) (1946). 
Thus, it would appear that disclosure aiding administration, not compassion for a bankrupt who is compelled to testify, was the pivotal consideration in the creation of the bankrupt's immunity. Yet, the question must immediately occur: If fullest disclosure be the dominant purpose of

1 the section 7 privilege, would not this end be best served by according a similar privilege to the testimony of every witness? Presumably so, but it seems reasonable to assume that the bankrupt was singled out, as a practical matter, ${ }^{24}$ because he would ordinarily be supposed to know more concerning his own business affairs than anyone else.

On the basis of the foregoing analysis, it seems clear that the designated representative of a corporate bankrupt testifying under section 7 a of the Act should be accorded the same immunity as would be accorded an individual bankrupt. There is compulsion to testify under pain of an action for contempt, ${ }^{25}$ and this representative is, after all, an equivalent reservoir of information pertaining to the bankrupt's property and business affairs. Thus, the corporate bankrupt's representative is presumably that person most likely possessed of the kind of information which must be disclosed if the bankrupt estate is effectively to be administered. Indeed, as a practical matter, the privilege of $\mathrm{za}(\mathrm{ro})$ is perhaps more necessary to furtherance of the public interest if a corporate representative is undergoing examination than if an individual bankrupt is being examined. In the latter case, the possibility of denial of discharge for failure to respond to material questions will ordinarily, of itself, militate in favor of disclosure. ${ }^{28}$ Matters of conscience aside, discharge of his corporate principal following adjudication is not of consequence to the typical corporate representative.

An argument could cenceivably be made that, at least to some extent, the immunity conferred by section 7 reflects legislative solicitude for the bankrupt. That is, the bankrupt might otherwise be in the awkward position of having to choose between waiver of the protection of the fifth amendment and forfeiture of the privilege of discharge. There is language in the committee reports possibly lending support to such a rationalization, ${ }^{27}$ which, indeed, would explain why the bankrupt was

${ }^{24}$ But see Note, 28 ST. JoHN's L. REv. 259, 265 (1954), where it is suggested that every witness examined should be entitled to the same degree of protection.

${ }^{35}$ See note 5 supra.

${ }^{30}$ See note 7 supra.

37 "It has been considered wise to exclude from the immunity of the testimony of the bankrupt that testimony which he gives upon his discharge proceeding. If he refuses to answer at the discharge hearing a material question upon the ground that it might 
singled out to benefit from the immunity. Even were this deemed a significant consideration in the creation of the $7 \mathrm{a}$ (IO) protection, however, it should accrue equally to the benefit of the representative of a corporate bankrupt, at least in those cases which appear to fall into that ill-defined area where conduct of the corporate representative might affect the possibility of his securing a discharge in any subsequent personal bankruptcy proceeding. ${ }^{28}$

\section{Sectron 2Ia}

If, for present purposes, it may be assumed that the same public interest would be served if the representative of a corporate bankrupt examined under section $7 \mathrm{a}$ were entitled to the same immunity as an individual bankrupt thereunder, it logically follows that the immunity of both, if it is to exist at all, should be identical under examinations pursuant to section $2 \mathrm{ra}$. Yet, even this broad premise cannot easily define the privilege of the representative of a corporate bankrupt, since there is some uncertainty as to the privilege of the individual bankrupt himself in this area.

The language of section $7 \mathrm{a}(\mathrm{IO})$ cannot be said unequivocally to indicate whether or not the immunity clause was intended to extend to section 2ra examinations. Opinions on this question may, however, be aligned as follows: Two dicta ${ }^{29}$ and one square holding ${ }^{30}$ urge that the immunity clause was intended to pertain only to examinations under sec-

tend to incriminate him, then he should be denied the privilege of discharge." H.R. REP. No. 1409 on H.R. 8046, 75th Cong., Ist Sess. 25 (1937). This language could be construed to imply that the immunity is accorded in other examinations in order to save for the bankrupt the privilege of discharge.

${ }^{38}$ This, admittedly, would be an extremely troublesome test to administer, for it is difficult enough to perceive wheu this effect would ensue even when benefited by a panoramic view of details of both the corporate and the individual bankruptcy proceedings. See In re Marcus, 149 F. Supp. 496 (S.D.N.Y. 1957), aff'd without reference to this issue, 253 F.2d 685 (1958), noted in 43 IowA L. REv. 406 (1958); Raphiel v. Morris Plau Industrial Bank of New York, 146 F.2d 340 (1944); In re Lesser, 234 Fed. 65 (2d Cir. 1916); Schieffelin \& Co., Inc. v. Herold, 222 F.2d 262 (2d Cir. 1955); I Collrer \$ 14.17; Krause, Denial of a Discharge to an Individual Bankrupt Who Makes a False Statement on Behalf of a Corporation, 32 REF. J. 111 (1958); Schwartz, Opposition to a Discharge by Reason of Acts or Conduct in Another Bankruptcy Proceeding, 20 REF. J. 57 (1946); Oglebay, Some Developments in Barkeruptcy Law, 19 REF. J. I07, III (1945).

${ }^{20}$ Cajiafas v. United States, 38 F.2d 3 (6th Cir. 1930); Goldstein v. United States, II F.2d 593 (5th Cir.), cert. denied, 27 I U.S. 667 (1926).

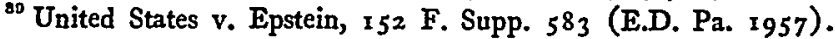


tion 7; two dicta ${ }^{31}$ suggest the contrary, a view in which most commentators concur. ${ }^{32}$

It is difficult to credit a congressional intent to distinguish in this manner between section 7 and section 2ra examinations ${ }^{33}$ for no satisfactory reason therefor readily appears. The two types of examination are closely interrelated, ${ }^{34}$ overlap to a certain extent, ${ }^{35}$ and, indeed, supplement each other in promoting fullest possible disclosure under the Act. Although examinations under section 2 ra must be generally limited in purpose to furthering administration of the estate, ${ }^{36}$ they may be conducted at any time subsequent to the filing of the petition $;^{37}$ even after adjudication. ${ }^{38}$ Indeed, as a matter of practice, the provisions of section 2ra are usually employed for all examinations of the bankrupt except those conducted at the first meeting of creditors and at the hearing on objections to his discharge. ${ }^{39}$ Moreover, it is only under section $2 \mathrm{ra}^{40}$ that officers and stockholders of a bankrupt corporation who ceased to be such prior to filing of the petition may be examined. ${ }^{41}$ Thus, it appears that examinations under section $2 \mathrm{Ia}$ are equally as important to

${ }^{31}$ United States v. Weissman, 219 F.2d 837 (2d Cir. 1955) (immunity can be claimed by sole shareholder of bankrupt corporation examined under $\S 2$ ra); In re Alphin \& Lake Cotton Co., $13 \times$ Fed. 825 (E.D. Ark. 1904) (implication that officers of bankrupt corporation could claim the immunity whether examined under $\S 7$ or $\S 2 \mathrm{a}$ ). It would seem logical to infer that a bankrupt can claim the immunity if a representative of a bankrupt can.

${ }^{3 s}$ E.g., 2 ColliER I $21.15 ; 5$ REMINGTON $\$ 2008$; Note, 28 ST. JoHN's L. REV. 259 (1954). In general, see Lipkin, Examinations under Section 2 sa of the Bankruptcy Act and Their Use in Subsequent Proceedings, 25 REF. J. 38 (1951).

${ }^{88}$ United States v. Epstein, 152 F. Supp. 583 (E.D. Pa. 1957), carefully considers the question but arrives at a conclusion which is hardly supported by some of the cases cited therein. Compare $i d$., at 586-88 and notes thereto, with 2 Collier I 21.15 n. 2. Moreover, the court, at $587 \mathrm{n}$. 11, purports to distinguish United States v. Weissman, 219 F.2d 837 (2d Cir. 1955), on the factual basis that in Epstein schedules had been signed by the bankrupt after adjudication, while in Weissman the sole shareholder had signed the schedules before adjudication. It appears, however, that in the Weissman case Judge Learned Hand did not rely on the signing of schedules per se to invoke the immunity, but rather noted in distinguishing In re Bush Terminal Co., 102 F.zd 47I (2d Cir. 1939), that the sole shareholder, having been directed by the court to sign the schedules, was identified with the bankrupt by virtue of the provisions of $\S 7 \mathrm{~b}$.

s4 5 REMINGTON § 2008.

${ }^{35}$ See note 2 supra.

${ }^{30} \mathrm{See} 2$ COLLIER I 2 1.07.

${ }^{28}$ Cameron v. United States, ${ }^{23}$ I U.S. $7 \times 0$ (1914); see 5 REMington $\S \times 987$.

${ }^{28}$ See 2 COLLIER I 21.07 .

20 See I COLLIER T 7.17.

${ }^{\circ}$ See note 15 supra.

"See 2 COLLIER T 21.09. 
successful administration of a bankrupt estate as those conducted under. section $7 \mathrm{a}^{42}$ and that only in conjunction do the two sections empower a court to secure full examinations of a bankrupt. ${ }^{43}$

Therefore, it seems evident that the same policy that requires the recognition of an immunity for testimony uttered at a first meeting of creditors is, to a marked extent, frustrated when that immunity is denied a bankrupt who appears for examination on some other occasion under section 21a. This conclusion is buttressed by the fact that the same legal compulsion to appear and to testify exists in both cases. Moreover, the bankrupt will lose his right to a discharge if he refuses to submit to a section $2 \mathrm{Ia}$ examination. ${ }^{44}$ By the same token, then, if the representative of a corporate bankrupt can claim a testimonial immunity under section 7 , identical to that of the bankrupt, when directed under section $7 \mathrm{~b}$ to submit to section 7 a examination, he should be able to claim that same immunity when subjected to a section 2 I examination. ${ }^{45}$

\footnotetext{
${ }^{12}$ See id. at I 21.08 . See also United States v. Weissman, 219 F.2d 837 (2d Cir. 1955); In re Alphin \& Lake Cotton Co., 13I Fed. 825 (E.D. Ark. 1904).

"Id. at $\mathbb{T} 21.15$.

"Ibid.

"s "We can see no reason for denying to such a person the protection that is given to the bankrupt, obviously for the purpose of insuring a full disclosure of the facts." United States v. Weissman, 219 F.2d 837, 841 (2d Cir. 1955).
} 